\title{
The application of groundwater modelling to simulate the behaviour of groundwater resources in the Ramhormooz Aquifer, Iran.
}

\begin{abstract}
In this study, groundwater modelling was proposed as management tool in Ramhormooz Plain, south western Iran. After definition of a conceptual model, the necessary data were defined into various packages of MODFLOW. Subsequently, the model was calibrated by trial and error estimation and the results were finally optimised by PMWIN through PEST code. After verification process, the model was used as a management tool for evaluating four management alternatives, including prediction of groundwater levels according to average historical recharge and discharge conditions, development of aquifer, prediction of aquifer response to installation of drainage and response against conjunctive use of surface water and groundwater in critical areas.
\end{abstract}

Keyword: Groundwater; Numerical modelling; MODFLOW; PMWIN. 